Erratum

\title{
Erratum: Muhammad, S.; Fathelrahman, E.; Tasbih Ullah, R.U. The Significance of Consumer's Awareness about Organic Food Products in the United Arab Emirates. Sustainability 2016, 8, 833
}

\author{
Safdar Muhammad, Eihab Fathelrahman * and Rafi Ullah Tasbih Ullah \\ Department of Agribusiness and Consumer Sciences, College of Food and Agriculture, United Arab Emirates \\ University, P.O. Box 15551 Al Ain, UAE; smuhammad@uaeu.ac.ae (S.M.); rafiullah.tasbih@uaeu.ac.ae (R.U.T.U.) \\ * Correspondence: eihab.fathelrahman@uaeu.ac.ae; Tel.: +11-971-03-713-4589
}

Received: 21 February 2017; Accepted: 21 February 2017; Published: 22 February 2017

The authors wish to make the following correction to their paper [1]. The name of the first author was misspelt. The correct name should be "Safdar Muhammad". The authors would like to apologize for any inconvenience caused. The change does not affect the scientific results. The manuscript will be updated and the original will remain online on the article webpage.

\section{Reference}

1. Muhammad, S.; Fathelrahman, E.; Tasbih Ullah, R.U. The Significance of Consumer's Awareness about Organic Food Products in the United Arab Emirates. Sustainability 2016, 8, 833. [CrossRef]

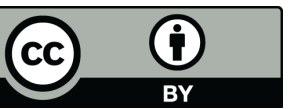

(C) 2017 by the authors. Licensee MDPI, Basel, Switzerland. This article is an open access article distributed under the terms and conditions of the Creative Commons Attribution (CC BY) license (http:/ / creativecommons.org/licenses/by/4.0/). 